\title{
Ethics
}

International Affairs

VOLUME 31 • NUMBER 2 - SUMMER 2017

\section{SPECIAL SECTION: Legitimate Authority, War, and the Ethics of Rebellion}

Christopher J. Finlay, Jonathan Parry, and Pål Wrange

\section{ESSAYS}

A Better Process, a Stronger UN SecretaryGeneral: How Historic Change Was Forged and What Comes Next

Yvonne Terlingen

Securing Protection for De Facto Refugees: The Case of Central America's Northern Triangle

Celia Medrano

FEATUR E

Pro Mundo Mori? The Problem of Cosmopolitan Motivation in War

Lior Erez

\section{REVIEW ESSAY}

Shifting International Security Norms

Denise Garcia

\section{REVIEWS}

Preventive Force: Drones, Targeted Killing, and the Transformation of Contemporary Warfare Kerstin Fisk and Jennifer Ramos REview By DoN SCHEID

Rethinking the New World Order

Georg Sørensen

ReVIEW by Jochen PRANTL 


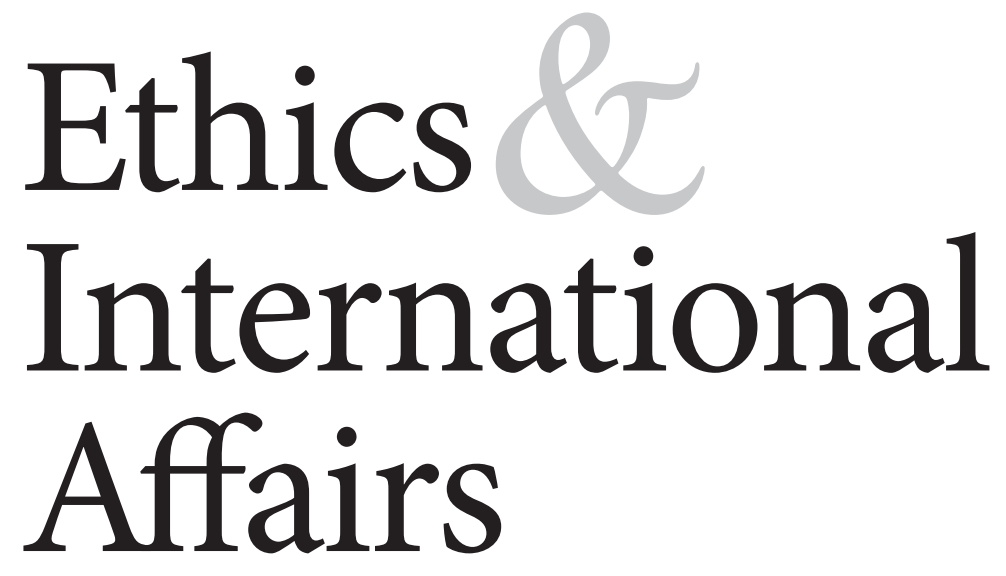

VOLUME $31 \cdot$ NUMBER $2 \cdot$ SUMMER 2017

\section{CARNEGIE}

The Voice for Ethics

in International Affairs 


\section{Ethics \& International Affairs}

THE JOURNAL OF THE CARNEGIE COUNCIL

EDITOR IN CHIEF Joel H. Rosenthal

EDITOR John Tessitore

MANAGING EDITOR Adam Read-Brown

ASSISTANT EDITOR John Krzyzaniak

EDITORIAL INTERN Emily Fox

COPY EDITOR Meghan Lynn

BUSINESS MANAGER Eva Becker

EDITORIAL ADVISORY BOARD

$\begin{array}{lll}\text { Christian Barry } & \text { Nikolas Gvosdev } & \text { David Rodin } \\ \text { Alex J. Bellamy } & \text { Ian Hurd } & \text { S. Prakash Sethi } \\ \text { Allen Buchanan } & \text { Anthony F. Lang, Jr. } & \text { Henry Shue } \\ \text { Deen K. Chatterjee } & \text { Anthony Langlois } & \text { Jennifer Welsh } \\ \text { Robyn Eckersley } & \text { David Luban } & \text { Leif Wenar } \\ \text { Ann Florini } & \text { David R. Mapel } & \\ \text { Joy Gordon } & \text { Darrel Moellendorf } & \end{array}$

\section{Carnegie Council for Ethics in International Affairs}

The Carnegie Council for Ethics in International Affairs is an independent, nonpartisan, nonsectarian, tax-exempt organization founded in 1914 by Andrew Carnegie. Since its beginnings, the Carnegie Council has asserted its strong belief that ethics, as informed by the world's principal moral and religious traditions, is an inevitable and integral component of all policy decisions, whether in the realm of economics, politics, or national security. The interrelationship of ethics and foreign policy is thus the unifying theme of all Carnegie Council programs. By promoting a greater understanding of the values and conditions that ensure peaceful relations among nations, the Carnegie Council hopes to contribute to a better life for people everywhere.

BOARD OF TRUSTEES

Kathleen Cheek-Milby

Niovi Christopolou

Jonathan E. Colby,

Treasurer

Barbara Crossette

Michael W. Doyle

Anthony L. Faillace

Jonathan Gage
Stephen D. Hibbard, Chairman

Haris Hromic

Bruce W. Jentleson, Vice Chairman

Susan King

Violy McCausland-Seve

Amir Pasic

HONORARY TRUSTEE Maurice S. Spanbock, Esq.

INTERNATIONAL HONORARY TRUSTEE Eiji Uehiro

SECRETARY OF THE CORPORATION Richard A. Edlin

Robert Perlman

Alexander H. Platt

Joel H. Rosenthal,

President

Robert G. Shaw

Michael J. Smith

Robert P. Smith 


\section{Contents}

Contributors 113

ESSAYS A Better Process, a Stronger UN Secretary-General: How Historic Change Was Forged and What Comes Next

Yvonne Terlingen 115

Securing Protection for De Facto Refugees: The Case of Central America's Northern Triangle

Celia Medrano 129

FEATURE Pro Mundo Mori? The Problem of Cosmopolitan Motivation in War Lior Erez 143

SPECIAL SECTION: Introduction 167

LEGITIMATE

AUTHORITY, WAR, AND THE ETHICS OF

Legitimate Authority and the Ethics of War: A Map of the Terrain Jonathan Parry 169

REBELLION Does Who Matter? Legal Authority and the Use of Military Violence Pål Wrange 191

The Perspective of the Rebel: A Gap in the Global Normative Architecture

Christopher J. Finlay 213

REVIEW ESSAY Shifting International Security Norms

Denise Garcia 235

REVIEWS Preventive Force: Drones, Targeted Killing, and the Transformation of Contemporary Warfare

Kerstin Fisk and Jennifer M. Ramos, eds.

Review by Don Scheid 247

Rethinking the New World Order

Georg Sørensen

Review by Jochen Prantl 249

Briefly Noted 253

SUBMISSIONS Guidelines for Submission 257

RESOURCES For additional Carnegie Council resources on the topics addressed in these pages, please visit www.ethicsandinternationalaffairs.org. 
ETHICS \& INTERNATIONAL AFFAIRS (ISSN 0892-6794 print; ISSN 1747-7093 online).

\section{Publisher}

Ethics \& International Affairs is published quarterly by Cambridge University Press, One Liberty Plaza, 2oth floor, New York, NY 10006.

\section{Information for subscribers}

Ethics \& International Affairs is published in four issues per year. Institutional subscription prices for 2017 are: Print \& Online: US $\$ 561$ in the USA, Canada, and Mexico; UK $\mathfrak{E}_{344}+$ VAT elsewhere. Institutions electronic only: US\$501 in the USA, Canada, and Mexico; UK£ $305+$ VAT elsewhere. Individuals print only: US\$45 in the USA, Canada, and Mexico; UK£ $30+$ VAT elsewhere. Correspondence concerning subscriptions should be sent to: Cambridge University Press, One Liberty Plaza, 2oth floor, New York, NY, USA for customers in the USA, Canada, or Mexico. Customers elsewhere should contact: Cambridge University Press, The Edinburgh Building, Shaftesbury Road, Cambridge $\mathrm{CB}_{2} 8 \mathrm{RU}$, UK. The price includes online access to the current and all online back files to January 1st 1997, where available.

\section{Delivery Terms and Legal Title}

Prices include delivery of print journals to the recipient's address. Delivery terms are Delivered Duty Unpaid (DDU); the recipient is responsible for paying any import duty or taxes. Legal title passes to the customer on despatch by our distributors.

Production Editor: Diane Davis (email: ddavis@cambridge.org).

Electronic Access Access to this journal is available free online within institutions in the developing world through the AGORA initiative with the FAO, the HINARI initiative with the WHO and the OARE initiative with UNEP. For information, visit www.aginternetwork.org, www.healthinternetwork.org, www.oarescience.org. Abstracting and Indexing Services The Journal is indexed by Academic Search (EBSCO), Academic Search Premier (EBSCO), CSA Environmental Sciences \& Pollution Management Database (CSA/CIG), CSA Sustainability Science Abstracts (CSA/CIG), Current Abstracts (EBSCO), Current Contents $\%$ Social and Behavioral Sciences (Thomson Reuters), Expanded Academic ASAP (Thomson Gale), IBSS: International Bibliography of the Social Sciences (LSE), InfoTrac, International Political Science Abstracts (IPSA), Journal Citation Reports/ Social Sciences Edition (Thomson Reuters), OMNIFILE Full Text Mega Edition (OMNIFILE), PAIS: Public Affairs Information Service (CSA/CIG), Proquest 5000 (ProQuest), Proquest Discovery (ProQuest), Proquest Platinum (ProQuest), Proquest Research Library (ProQuest), Proquest Social Science Journals (ProQuest), Social Sciences Citation Index ${ }^{\infty}$ (Thomson Reuters), Social Sciences Index/Abstracts (HW Wilson), Student Resource Center College (w/ Academic ASAP),Wilson OMNIFILE Full Text Select (HW Wilson) and Worldwide Political Sciences Abstracts (CSA/CIG).

Disclaimer The Publisher, Carnegie Council, and Editors cannot be held responsible for errors or any consequences arising from the use of information contained in this journal; the views and opinions expressed do not necessarily reflect those of the Publisher, Council and Editors, neither does the publication of advertisements constitute any endorsement by the Publisher, Council and Editors of the products advertised.

Copyright and Photocopying Copyright (C) 2017 Carnegie Council for Ethics in International Affairs. All rights reserved. No part of this publication may be reproduced, in any form or by any means, electronic, photocopying, or otherwise, without permission in writing from Cambridge University Press. Policies, request forms, and contacts are available at: http://www.cambridge.org/rights/permissions/permission.htm Permission to copy (for users in the U.S.A.) is available from Copyright Clearance Center, http://www.copyright.com, email: info@copyright.com.

Printed in USA by The Sheridan Press.

View this journal online at journals.cambridge.org/EIA.

ISSN 0892-6794 (Print)

ISSN 1747-7093 (Online) 


\section{Ethics \& International Affairs}

